To Maega | Jurnal Pengabdian Masyarakat

Agustus-2021, Vol.4, No.2, hal. 145-152

$\operatorname{ISSN}(P): 2622-6332 ; \operatorname{ISSN}(E): 2622-6340$

http://www.ojs.unanda.ac.id/index.php/tomaega

\title{
Penyuluhan Hukum tentang Tindak Pidana Korupsi kepada Badan Koordinator Organisasi Wanita Provinsi Kepulauan Riau
}

\author{
Heni Widiyani ${ }^{1 *}$, Ayu Efritadewi ${ }^{1}$, Elfa Oprasmani ${ }^{2}$, Marisa Elsera ${ }^{3}$, Muhammad \\ Jova Febrianto ${ }^{1}$ \\ ${ }^{1}$ IImu Hukum, FISIP , Universitas Maritim Raja Ali Haji \\ 2 Pendidikan Biologi, FKIP, Universitas Maritim Raja Ali Haji \\ ${ }^{3}$ Sosiologi, FISIP, Universitas Maritim Raja Ali Haji \\ *CorrespondentEmail: heni@umrah.ac.id \\ Article History: \\ Received: 22-01-2021; Received in Revised: 07-03-2021; Accepted: 08-04-2021 \\ DOI: http://dx.doi.org/10.35914/tomaega.v4i2.610
}

\begin{abstract}
Abstrak
Saat ini banyak sekali terjadi kasus korupsi di pemerintahan maupun sektor swasta dilakukan oleh para lelaki yang sudah memiliki istri dan anak.Dengan adanya penyuluhan ini, diharapkan wanita khususnya anggota BKOW bisa menjadi pelopor dirumah tangga untuk membentuk keluarga anti korupsi baik kepada anak dan suami. Kegiatan pengabdian ini dilakukan dengan 4 metode yakni: ceramah, dialog, bedah kasus, dan best practice. Hasil dari kegiatan ini, peserta menjadi antusias, yang terlihat dari banyaknya pertanyan yang diajukan serta terbentuknya komunikasi yang baik. Pengabdian ini perlu dilanjutkan kembali, di organisasiorganisasi wanita lainnya agar penyampaian ini mencakup banyak wanita aktif di kepulauan Riau.
\end{abstract}

Kata Kunci: Penyuluhan Hukum, Korupsi, Organisasi Wanita.

\begin{abstract}
Nowadays there are many cases of corruption in the government and private sector carried out by men who already have wives and children. With this counseling, it is hoped that women, especially BKOW members, can be pioneers in the household to form an anti-corruption family for both children and husbands. This devotional activity is carried out with 4 methods namely: lectures, dialogue, case surgery, and best practice. As a result of this activity, participants became enthusiastic, which was evident from the many questions raised as well as the formation of good communication. This service needs to be resumed, in other women's organizations in order for this delivery to include many active women in Riau islands.
\end{abstract}

Keywords: Legal Counseling, Corruption, Women's Organizations. 


\section{Pendahuluan}

Tindak pidana korupsi di Indonesia saat ini masih menjadi permasalahan penting yang harus dicegah dan diatasi oleh pemerintah Indonesia. Hal ini dikarenakan dampak yang timbulkan akibat tindak pidana ini tidak hanya berkaitan dengan kerugian keuangan negara tetapi juga merusak nilai keadilan dan etika. Tindak pidana korupsi ini juga dapat membahayakan terhadap nilai moral serta intelektual masyarakat (Setiadi, 2018). Tindak pidana korupsi juga membahayakan norma serta budaya yang ada di masyarakat. Apabila tindak pidana ini sering terjadi di masyarakat dan menjadi kebiasaan di masyarakat, maka korupsi akan mendarah daging dan lambat laun menjadi norma dan budaya di masyarakat (KPK, 2016).

Belakangan ini telah banyak gerakan anti korupsi yang dilakukan di masyarakat, namun gerakan anti korupsi ini kebanyakan dilakukan oleh laki-laki dibandingkan perempuan. Hal ini dikarenakan oleh adanya pandangan bahwa perempuan bukan penentu aktivitas yang berkaitan dengan laki-laki, atau dengan kata lain perempuan hanya memegang peran kedua (Purwanto, 2015). Padahal di lapangan, banyak perempuan terutama istri maupun anak yang menjadi korban serta memikul sanksi sosial yang berat akibat tindakan korupsi yang dilakukan oleh laki-laki atau suaminya. Meskipun ditemukan beberapa kasus perempuan juga tersangkut masalah korupsi atau menjadi bagian dari korupsi dengan menikmati hasil korupsi (Kusumastuti dan Supriyanta, 2017).

Sehingga diperlukan upaya yang tepat dalam mengatasi dan mencegah terjadinya permasalahan ini. Salah satu upaya yang dapat dilakukan yakni dengan memberikan pemahaman/pendidikan kepada masyarakat tentang penanaman nilai anti korupsi, terutama pada perempuan. Hal ini karena perempuan khususnya para istri/ibu memiliki peran penting dalam pendidikan keluarga (Permana, 2017). Sehingga perempuan memiliki peran strategis sebagai agen perubahan pada skala keluarga untuk menanamkan nilai-nilai tentang anti korupsi. Perempuan dapat berperan sebagai agen kontrol dalam mencegah keluarga atau orang-orang terdekatnya untuk tidak melakukan tindakan korupsi (Bilondatu, 2018). Selain itu berdasarkan penelitian yang dilakukan oleh Martha dan Hastuti (2013) bahwa perempuan memiliki perilaku yang mendukung upaya anti korupsi daripada laki-laki.

Seiring dengan perkembangan zaman, keikutsertaan perempuan dalam berbagai aspek kehidupan juga semakin terlihat. Saat ini banyak perempuan yang juga berperan dalam sektor publik dan organisasi perempuan selain menjalankan perannya sebagai ibu dan seorang istri dalam keluarganya. Perempuan saat ini memiliki posisi penentu baik dalam perusahaan maupun profesi di berbagai bidang, sehingga perempuan memiliki peran sebagai ibu, istri, anggota dalam komunitas atau rekan kerja yang memiliki kekuatan dominan dalam pemberantasan korupsi (Kusumastuti dan Supriyanta, 2017). Untuk membuka pandangan dan menambah wawasan para perempuan dalam gerakan antikorupsi, dapat dilakukan edukasi melalui organisasi perempuan yang ada. 
Salah satu organisasi perempuan yang ada di Kepulauan Riau yakni Badan Kerjasama Organisasi Wanita (BKOW) Kepulauan Riau. BKOW ini berdiri pada tanggal 4 Desember 2006 di Tanjungpinang melalui musyawarah daerah organisasi wanita. Organisasi ini bertujuan dalam membantu pemerintah menjalankan programprogram seperti kesehatan, ekonomi, pemberdayaan dan pendidikan. Dengan adanya BKOW ini diharapkan anggota-anggota yang tergabung dapat meningkatkan potensi serta mengasah kemandiriannya serta dibekali dengan keterampilan yang diberikan BKOW.

BKOW ini juga dapat menjadi wadah dalam menyalurkan aspirasi, potensi peran, serta akses bagi perempuan untuk mendukung program-program pembangunan daerah, sehingga diharapkan dengan adanya organisasi ini perempuan-perempuan di Kepulauan Riau dapat memberikan kesempatan supaya para perempuan dapat memaksimalkan potensi yang ada pada diri mereka. Apabila potensi perempuan dapat diberdayakan maka perempuan-perempuan di Kepulauan Riau akan menjadi penggerak perubahan. Berbagai aktivitas atau kegiatan dalam bentuk pemberdayaan secara terus menerus diharapkan dapat menyebabkan perubahan sosial (Muryanti dkk, 2018). Dengan adanya jaringan sosial atau kelompok organisasi perempuan yang tidak hanya berfungsi sebagai paguyuban tetapi juga merupakan sarana informasi yang sesuai dan mendukung dalam bekerjasama khususnya dalam memberantas dan mencegah tindakan korupsi. Melalui keikutsertaan perempuan dalam sebuah komunitas atau jejaring, perempuan dapat memasukkan pendidikan dan sosialisasi mengenai kejujuran serta perbaikan moral (Kusumastuti dan Supriyanta, 2017).

Sehingga diharapkan dengan kegiatan pengabdian masyarakat melalui pemberian penyuluhan anti korupsi di BKOW Kepulauan Riau bisa menambah khasanah para wanita untuk ikut dalam pemberantasan korupsi di negeri ini. Kegiatan penyuluhan pada perempuan khususnya anggota BKOW bisa menjadi pelopor dalam rumah tangga untuk membentuk keluarga anti korupsi baik kepada anak dan suami.

\section{Metode}

Kegiatan pengabdian masyarakat dengan tema Peyuluhan Hukum tentang Tindak Pidana Korupsi kepada Badan Koordinator Organisasi Wanita Provinsi kepulauanRiau.dilakukan dengan metode berikut :

1. Ceramah : metode ini dilakukan melalui penyampaian materi dari tim Pengabdian Kepada Masyarakat kepada Organisasi BKOW yang menjadi target dalam kegiatan pengabdian masyarakat ini.

2. Dialog : metode ini dilakukan dengan cara adanya komunikasi dua arah antara pemateri dengan anggota BKOW yang menjadi target dalam kegiatan pengabdian masyarakat.

3. Bedah kasus : metode ini dilakukan dengan melakukan bedah kasus Korupsi yang terjadi di kota Tanjungpinang, seperti kasus korupsi Mantan Gubernur 
Kepulauan Riau, NBA. Korupsi dengan nilai Rp. 41.000 .000 dan 11.000 dolar Singapore (KPK, 2019)

4. Best practice : metode ini dilakukan dengan cara memberikan contoh-contoh sikap yang baik agar menghindari sikap koruptif.

\section{Hasil dan Pembahasan}

Kegiatan pengabdian dilaksanakan pada tanggal 23 Juli 2020 di Ruangan BKOW Gedung Daerah. Kegiatan ini dihadiri oleh anggota BKOW yang berasal dari semua organisasi wanita yang ada di Kepulauan Riau. Kegiatan pengabdian ini dibuka oleh Ketua 3 yang membawahi Bidang Hukum dan HAM. Hal ini dikarenakan Ketua BKOW yang juga merupakan ibu Gubernur Kepulauan Riau sedang berada di luar kota mendampingi bapak Gubernur dalam urusan kedinasan. Kegiatan pengabdian ini dipandu oleh mahasiswa hukum semester 5 yaitu Putri Handayani, Tiwi Kumala Sari, Nur, Evi dan Sri Rahayu.

Pengetahuan tentang korupsi ini penting diberikan kepada anggota BKOW, karena anggota BKOW mayoritas merupakan ibu rumah tangga yang memiliki suami pejabat tinggi di Kepulauan Riau.Anggota BKOW juga merupakan wanita yang aktif di tengah masyarakat, baik sebagai penggerak dibidang sosial maupun agama. Dengan adanya penyuluhan/ sosialisasi, diharapkan mampu meningkatkan kesadaran anggota BKOW tentang pentingnya ikut serta dalam pencegahan korupsi.Sosialisasi/penyuluhan dapat membuka pola pikir dan meningkatkan wawasan masyarakat, sehingga mampu meningkatkan kesadaran masyarakat (Oprasmani dkk, 2020).

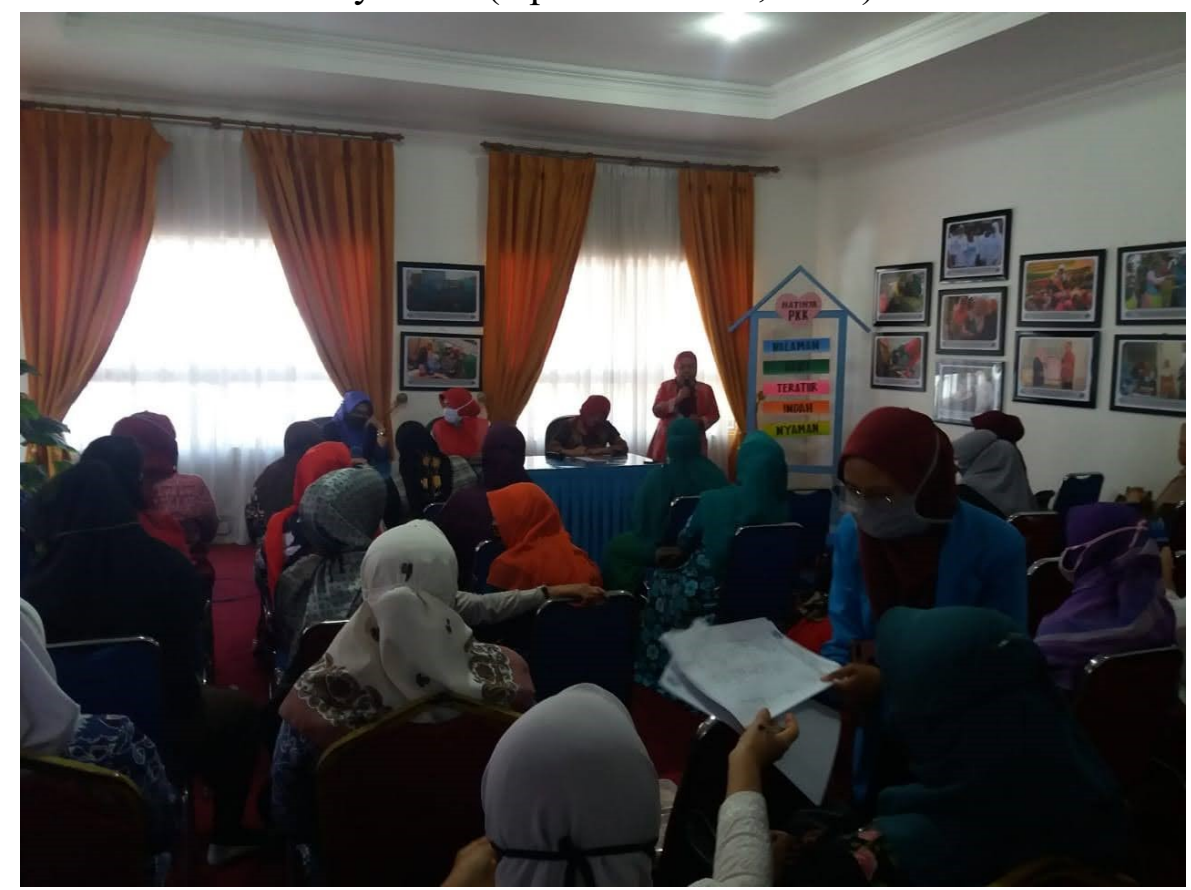

Gambar 1. Kegiatan Pengabdian di BKOW Kepulauan Riau 
Pada sosialisasi ini yang bertindak sebagai pemateri yakni dari tim PKM yang menjelaskan alasan mengapa perempuan perlu terlibat dalam pencegahan korupsi. Hal ini dikarenakan perempuan dapat menjadi agen yang luar biasa dalam pencegahan korupsi mulai dari lingkup keluarga. KPK memandang bahwa untuk dapat memberantas korupsi, perlu menyentuh kelompok terkecil dari masyarakat, seperti keluarga (Kusumastuti dan Supriyanta, 2017). Sehingga perempuan harus memahami tentang seluk beluk korupsi, agar dapat mencegah keluarganya terlibat dalam lingkaran kelam korupsi. Selain itu juga dibahas bahwa perempuan mampu memutus lingkaran korupsi dengan membentuk lingkaran integritas (penolakan terhadap korupsi) sehingga akan membatalkan niat dan menghapuskan tindak korupsi. Pemateri juga memberikan sebuah kasus tentang korupsi yang akhirnya merugikan perempuan sebagai istri.

Salah satu kasus korupsi yang diangkat dalam pengabdian ini adalah kasus korupsi terjadi di Kota Tanjungpinang. Kasus korupsi yang dilakukan oleh NBA (Mantan Gubernur Kepulauan Riau). Pada kasus korupsi, NBA ditetapkan sebagai tersangka dengan dugaan suap terkait dengan izin prinsip dan lokasi pemanfaatan laut, proyek reklamasi wilayah pesisir dan pulau kecil serta gratifikasi yang berhubungan dengan jabatan (KPK, 2019). Korupsi yang dilakukan NBA dengan nilai Rp. 41.000.000 dan 11.000 dolar Singapura. Pada kasus ini NBA dituntut 6 tahun penjara dan denda Rp. 250.000 .000 subsider 6 bulan tahanan dalam kasus korupsi. Dampak lain dari korupsi yang dilakukan oleh seorang suami seperti kasus tersebut, adalah sanksi sosial yang harus dipikul oleh istri dan anak-anaknya. Beberapa kasus menunjukkan bahwa tidak jarang istri dan anak-anak dari tersangka tindak pidana korupsi menjadi malu, diasingkan bahkan berhenti dari sekolah (Purwanto, 2015). Sehingga peran perempuan sangat penting dalam mencegah suami dalam melakukan tindakan korupsi.

Pembahasan selanjutnya yaitu tentang bagaimana cara mendidik anak untuk mempunyai sifat yang baik agar tidak melakukan tindakan koruptif sedari kecil. Hal ini dilakukan agar para peserta sosialisasi juga dapat mengarahkan anak-anak mereka untuk mempunyai sifat jujur dan bertanggung jawab dalam setiap kegiatan. Sehingga anakanak dapat menjadi penerus bangsa yang bebas dari sifat koruptif apabila menduduki jabatan tertentu dikemudian hari. Perempuan dapat menjadi penentu masa depan dengan membentuk generasi yang tangguh serta mampu melawan dan mencegah korupsi (Rozuli, 2018).

Dalam sosialisasi juga dijelaskan tentang contoh sikap yang akan menjadi cikal bakal timbulnya sifat koruptif dimasa depan, cara mengarahkan anak-anak di rumah untuk berperan serta dalam bermusyawarah untuk menyelesaikan permasalahanpermasalahan yang dihadapi, serta agar ada keterbukaan antara anak-anak dan orang tua. Hal ini bertujuan agar peserta sosialisasi mampu menciptakan suasana yang harmonis sehingga akan menimbulkan kepercayaan anak kepada orang tua dan ketika kepercayaan itu muncul maka nasehat dan ajaran orang tua akan mudah di terima oleh anak anak. Perempuan sebagai seorang ibu harus dapat menjadi role model serta memiliki pola asuh yang baik bagi anak-anaknya, sehingga dapat menanamkan karakter 
sederhana, jujur serta bertanggung jawab sebagai pondasi untuk menginternalisasi budaya antikorupsi pada anak (Purwanto, 2015). Peran perempuan dalam keluarga tidak hanya dalam menginternalisasikan budaya antikorupsi kepada anak, tetapi juga mencegah suami dalam melakukan korupsi dengan memberikan kasih sayang, empati, pengurusan rumah tangga yang baik serta tidak banyak menuntut dalam pemenuhan materi (Azzuhri, 2011).

Peserta sosialisasi terlihat sangat antusias dalam mendengarkan materi tentang korupsi ini. Hal ini terlihat dari pertanyaan peserta sosialisasi yang menanyakan tentang bagaimana caramereka harus menyikapi masalah korupsi ini sehingga tidak terjadi dikeluarga mereka, penjelasan pasal dalam tindak pidana korupsi, serta bagaimana menghadapi jika ada dalam keluarga yang terlibat dalam tindak pidana korupsi. Pemberian materi tentang korupsi ini diharapkan mereka sebagai bisa menjadi pelopor penggerak anti korupsi di tengah masyarakat.

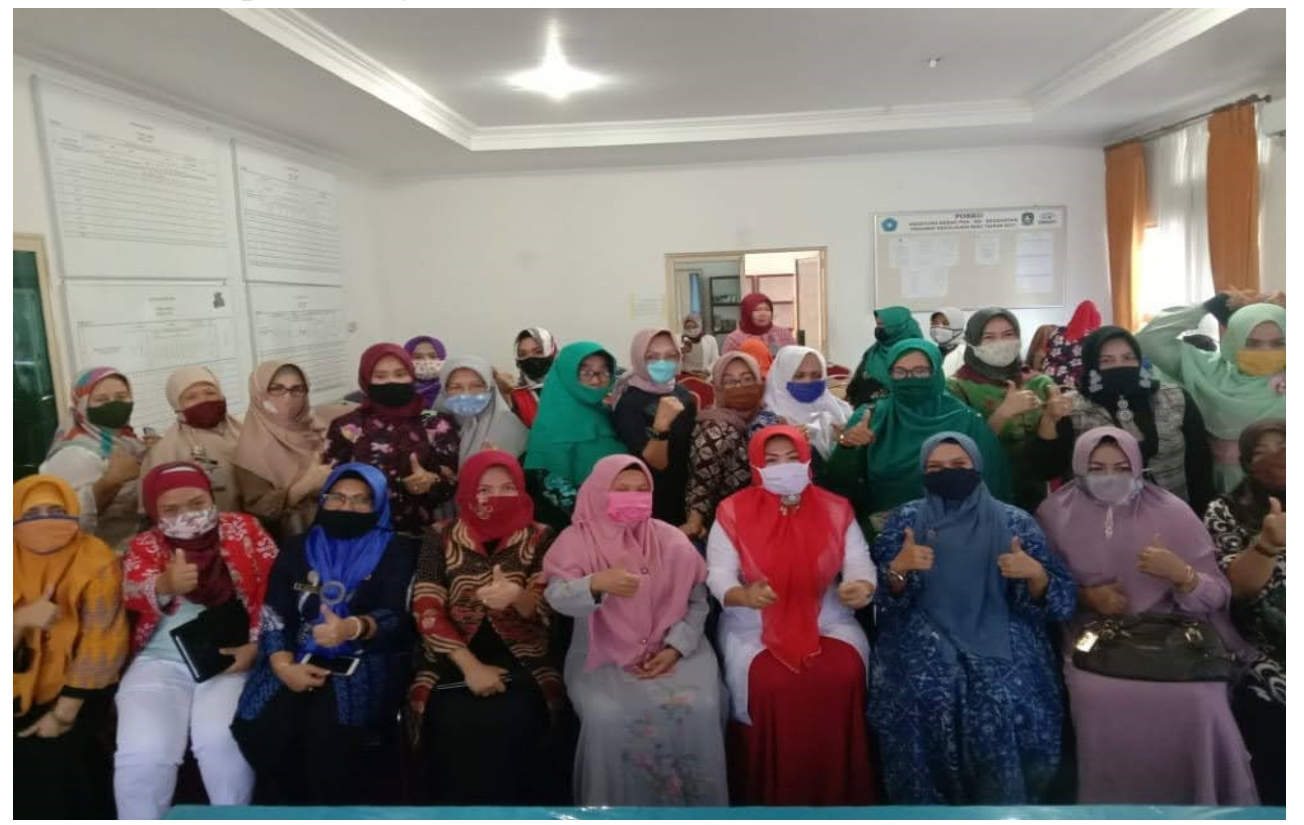

Gambar 2. Foto Bersama Peserta Sosialisasi

Dengan adanya sosialisasi tentang korupsi ini diharapkan kedepannya anggota BKOW bisa menjadi pelopor dari gerakan perempuan anti korupsi yang mengetahui tentang korupsi baik secara logika maupun teori Hukumnya, Pengabdian ini dilanjutkan dengan pemberian buku modul dari Komisi Pemberantasan Korupsi, secara simbolis diterima oleh ibu Ketua 3. Diharapkan dengan buku ini ibu-ibu bisa membaca dengan keluarga di rumah, mendiskusikannya, dan bisa menambah wawasan keluarga tentang korupsi.

Kegiatan ini perlu dilakukan secara berkelanjutan agar dapat memberikan wawasan dan merubah polapikir perempuan sehingga mampu menjadi agen untuk memutus mata rantai korupsi yang ada di Kepulauan Riau. Pada kegiatan ini hanya terbatas sosialisasi saja, dalam kegiatan sosialisasi peserta terlihat antusias. Dalam 
kegiatan ini belum terdapat evaluasi setelah dilakukan pengabdian. sehingga belum terlihat sejauh mana pemahaman peserta sosialisasi terhadap materi yang diberikan.

\section{Kesimpulan dan Saran}

Pengabdian tentang tindak pidana korupsi di Organisasi BKOW berjalan dengan baik di Gedung Sekretariat BKOW, terlihat dari antusias anggota yang datang di acara ini, serta banyaknya pertanyan yang diajukan serta terbentuknya komunikasi yang baik. Pengabdian ini perlu di lanjutkan kembali, di organisasi-organisasi wanita lainnya agar penyampaian ini mencakup banyak wanita aktif di kepulauan Riau.

Kegiatan ini diharapkan dapat terus dilanjutkan agar lebih banyak perempuan yang lebih paham tentang tindak pidana, dan menyarankan ada kegiatan rutin ke organisasi anggota BKOW lainya.Anggota juga meminta agar para akademisi khususnya di bidang hukum banyak memberikan pengetahuan Hukum secara teori dan praktek kepada mereka.

\section{Ucapan Terimakasih}

Ucapan terimakasih ditujukan kepada Universitas Maritim Raja Ali Haji, Program Studi Hukum, Anggota BKOW Kepulauan Riau, Mahasiswa yang terlibat dan pihak-pihak yang terkait dengan terlaksananya kegiatan pengabdian ini.

\section{Daftar Pustaka}

Azzuhri, M. (2011). Pemberdayaan Perempuan dalam Membangun Budaya Anti Korupsi. Muwazah, 3 (2), 466-472.

Bilondatu, A. A. (2018). Ekspektasi Perempuan Dalam Pemberantasan Tindak Pidana Korupsi. Gorontalo Law Review, 1 (2), 32-40. DOI: 10.32662/golrev.v1i2.372.

KPK. (2016). Dampak Sosial Korupsi. Jakarta: Direktorat Pendidikan dan Pelayanan Masyarakat Kedeputian Bidang Pencegahan.

. (2019). Siaran Pers: KPK Tetapkan Gubernur Kepulauan Riau Sebagai Tersangka.. Https://kpk.go.id/id/berita/siaran-pers/1057-kpk-tetapkangubernur-kepulauan-riau-sebagai-tersangka. Diakses 14 Februari 2021.

Kusumastuti, D. dan Supriyanta. (2017). Peran Perempuan Dalam Pencegahan Korupsi Di Indonesia (Pengabdian Masyarakat Pada PKK Kelurahan Wonorejo Karanganyar). ADIWIYA, 1(1), 11-18.

Martha, A. E. dan D. Hastuti. (2013). Gender dan Korupsi (Pengaruh Kesetaraan Gender DPRD dalam Pemberantasan Korupsi di Kota Yogyakarta). Jurnal Hukum IUS QUIA IUSTUM, 4 (20), 580-601. DOI: 10.20885/iustum.vol20.iss4.art5. 
Muryanti, T. Muryani dan C. Lestari. (2018). Pemberdayaan Perempuan Melalui Gerakan Saya Perempuan Antikorupsi (SPAK) Di Yogyakarta. Musawa, 17 (1), 86-94. DOI: 10.14421/musawa.1.171.86-94.

Oprasmani, E., T. Amelia dan E. Muhartati. (2020). Membangun Masyarakat Peduli Lingkungan Pesisir Melalui Edukasi Kepada Masyarakat Kota Tanjungpinang Terkait Pelestarian Daerah Pesisir. To Maega, 3 (2), 66-73. DOI: 10.35914/tomaega.v3i2.372.

Permana, F.Y. (2017). Perempuan Dalam Kampanye Antikorupsi. Jurnal ASPIKOM, 3 (3), 400-413. DOI: 10.24329/aspikom.v3i3.142.

Purwanto. (2015). Rekonstruksi Peran Kelembagaan Perempuan Dalam Gerakan Anti Korupsi Di Kalimantan Barat. Masalah-Masalah Hukum, 44 (1), 44-51. DOI: $10.14710 / \mathrm{mmh} .44 .1 .2015 .44-51$.

Rozuli, A. I. (2018). Perempuan, Kekuasaan dan Korupsi. Jurnal Transformative 4 (1), 33-44. https://transformative.ub.ac.id/index.php/jtr/article/view/13.

Setiadi, W. (2018). Korupsi Di Indonesia (Penyebab, Bahaya, Hambatan dan Upaya Pemberantasan, Serta Regulasi). Jurnal Legislasi Indonesia, 15 (2), 249-262. https://e-jurnal.peraturan.go.id/index.php/jli/article/view/234/pdf. 